\title{
WOMEN, HOUSEHOLD AND HEALTH IN LATIN AMERICA
}

\author{
C. H. BROWNER \\ Department of Psychiatry and Biobehavioral Sciences, University of California, Los Angeles.
} CA 90024 , U.S.A.

\begin{abstract}
Although recent studies have identified some of the links in Latin America between uneven capitalist economic development and health, the impact of development on either the health of women or on household health is still largely unknown. This account identifies several areas of needed research. It focuses on how changing women's roles and patterns of domestic production affect women's reproductive behavior, and the consequences of these changes for the health of women and other members of their households.
\end{abstract}

Key words - health, development, women, households, Latin America

\section{INTRODUCTION}

Although recent studies have identified some of the links in Latin America between uneven capitalist economic development and health [1-14], the impact of development on either the health of women or on household health is largely unknown. This account will identify areas where research is vitally needed, focusing on how changing patterns of household production affect women's fertility and their reproductive behavior. It also considers the health consequences of these changes both for women and other members of their households. Throughout Latin America, the discrete yet interconnected systems of social class and gender stratification influence women's health status and shape their experiences as health care consumers and health care providers in the home. Analyses of the multiple links between these two systems and the forces that work to maintain them are essential if we wish to illuminate the full impact of socioeconomic development on health, health care, and illness. My points will be made with data drawn primarily from Latin America because it is the world that I know best. The extent to which the patterns I describe are also true for other parts of the developing world is subject to future investigation.

The paper is divided into three parts. The first examines how interactions between Latin American women's reproductive and productive roles affect their own health. The second describes how social reproduction at the household level is achieved in part through women's activities as health educators and health care providers in the home. In the last section, I show how the structure, organization, and distribution of resources and power within households may aiso affect women's health and that of other household members. My intent is to demonstrate that households can provide powerful analytical units through which to evaluate the health consequences of uneven capitalist development in Latin America because they link individuals to broader social structural units and provide a fundamental context for daily life.
Whenever possible, illustrative examples are taken from the literature or from my own ethnographic field work in urban Colombia $(1974-75 ; 1978)$ and rural Mexico (1980-81) on interactions between women's productive and reproductive roles and their health. Materials will come from Latin America unless there is no Latin American literature on the subject, in which case data to identify areas for future research will be drawn from elsewhere. It should be cautioned that the national, social class, and rural-urban differences found throughout Latin America may make comparisons difficult, and that generalizations must be cautiously made

\section{PRODUCTION, REPRODUCTION, AND WOMEN'S HEALTH}

Recent feminist scholarship has documented how women's role in biological and social reproduction may structure their productive activities, and how, in turn, women's productive activities may influence their reproductive behavior [15-18]. Yet little attention has been paid to examining how the patterning of these relationships may affect women's health \{although research by Medrano and Villar [19] on female flower cultivators in Colombia and by Carrillo and Jasis [20] and Fernández Kelly [21] on women working in the export-manufacturing plants (maquiladoras) along the U.S.-Mexican border are important exceptions\}. This neglect can be attributed partly to the fact that the health of the Third World workers in general has been largely ignored [22], and to the cultural stereotype that Latin American women are not 'workers' but rather mothers and wives. Due to this bias, most research on women's health in Latin America, as in the rest of the developing world, focuses on the health consequences of high fertility $[23,24]$.

But women constitute a large and growing proportion of the Latin American labor force, with their participation averaging about $25 \%$ of paid workers throughout the region [25-28]. Therefore, although we still need to gain a better understanding of the 
impact of work on the health of Latin Americans as a whole, there are special considerations that apply to working women.* This section describes some of the ways that interactions between Latin American women's reproductive and productive roles may negatively affect their health. In cases where there is little empirical work to draw on, I identify directions for future research. It should be noted that while much of the literature attributes primacy to either productive or reproductive processes $[29,30]$, in reality the two are one single process and should be analyzed together.

The health consequences of combining family and work roles

Whether or not they also work outside their homes, most Latin America women spend long hours engaged in child care and housework. A recent survey on unremunerated domestic work in eight Latin American and Caribbean countries revealed that homeworkers averaged between 57 and $99 \mathrm{hr}$ a week in housework [25, p. 10]! Working women typically spend only slightly less time in domestic labor than do full time housewives and for this reason are said to work a 'double day'. In all cases where quantitative data are available, they consistently show that both employed women and full time housewives work more hours each day than their husbands [31]. We still know little about the health effects of maintaining dual work and family roles, but Stellman has described some of the potential interactions:

.. some of the major health hazards for women at work complement and exacerbate hazards at home. Back injuries and backaches are common to workers on the job as well as to the mother of young children and to the housekeeper at home. Skin irritation and disease are widespread among hospital workers, service workers, and industrial workers just as they are among women in the home role. ... Women who care for children at home are also exposed to the many infectious illnesses that young people contract. And, of course, fatigue from long hours of housework and responsibilities is endemic to the dual role of homemaker and worker [32]

The limited data available from industrialized countries show that combining work and family roles is not necessarily harmful to women's health. Although women report higher rates of acute conditions and make greater use of health services than men, they usually live longer and have fewer chronic conditions, differences which are seen regardless of their employment situation [33-35]. In the U.S. working women appear to experience better overall health than housewives as evidenced by the fact that they report fewer chronic conditions, symptoms, and days of bed rest or restricted activity [36]. Working women, however, do report slightly more acute conditions than housewives, a finding which supports Stellman's observations above.

Yet Waldron cautions that we lack sufficient data to establish the effects of employment on women's

*The term 'working women' refers here to those whose economic activities generate cash. By its use 1 do not imply that women who are exclusively homemakers do not 'work' and contribute importantly to their family's subsistence. health, for the observed patterns are influenced both by the effects of employment on health and the effects of health on employment. Longitudinal data would be needed to confidently distinguish between these effects and to establish the magnitude of the differences between groups. Data from developing countries, such as those in Latin America, would also be needed before generalizations for women living in these social and economic settings could be made. For, regardless of their employment situations, the majority of Latin American women are in worse health than women in industrialized countries, as data on mortality and life expectancy clearly show $[10,1980-1983 ; 24$, p. 87]. The effects of working a 'double day' might therefore weigh more heavily on Latin American women, particularly because they generally encounter longer workdays, poorer working conditions, and fewer employee benefits than women in industrialized nations.

This is because the economic activitics of a great many Latin American women are restricted to the 'informal' sector of the economy. This sector consists of jobs which can be carried out intermittently on an irregular basis [26, p. 36]. Although the precise number of women who work in this labor sector is difficult to determine, the data show that a far larger proportion of working women than working men carry out informal economic activities. For example, Merrick found in one Brazilian city that nearly half the female household heads were employed in the informal sector. This was more than three times the proportion of male household heads who were similarly employed [37]. In some Latin American cities, the earnings of up to half of working women come from this economic sector $[38,39]$.

Those who work $:$ the informal sector do so largely because they are blocked from more stable and lucrative formal sector employment. The underdeveloped but labor-rich Latin American economies cannot provide employment for all who seek work. Moreover, the sexism that permeates all aspects of Latin American society results in extreme labor market segmentation with the allocation of the better jobs to men. Finally, women often lack the skills or training to successfully compete for formal sector work. But some women also regard informal sector employment advantageous because of its flexible hours and the fact that it can more easily be combined with simultaneous child care than most formal sector jobs allow [40]. Working in Peru, for instance, Bunster found that one group of market women chose their work in part because they could combine it with child care, and because their children could help with the women's marketing activities [41].

Women's work in the informal sector covers a wide range of activities from middle class occupations such as private tutoring and skilled crafts production to lower class jobs including street vending, the production and sale of produce and handicrafts, domestic work, child care, and prostitution. Despite this occupational diversity, jobs in the informal sector share a number of common characteristics, all of which are likely to have negative consequences for the health of the employed, and in some cases for their families as well. Pay in the informal sector is ordinarily lower than in the formal one. There are no labor contracts, 
and workers are excluded from the benefits of protective legislation determining job conditions, length of the work week, hours of employment, and the like. Health, disability, unemployment insurance, and severance pay are not provided; employment is often sporadic. The absence of any regulatory pressures from external agencies may also increase the likelihood that those in the informal sector work in unsafe and unhealthy conditions.

Lacking data, we can only speculate on the implications of employment in the informal sector for the health of women workers, but the following are some likely outcomes: the lower wages of workers in the informal sector may make in difficult for them to provide themselves and their dependents with adequate food, safe water, satisfactory living conditions, and medical care. Because they lack sick leave, they are less able to take time off from work when they are ill. They may be similarly unable to stay home to care for sick or disabled family members when those people become ill.

\section{Reproductive health risks to women workers}

Because women's bodies are specialized for biological reproduction, work environments may impact upon their health differently than they do upon men's. Occupational hazards such as excessive noise, poor lighting and ventilation, and the presence of infectious or poisonous agents will presumably affect the health of both sexes equally. However, differences in female and male reproductive biology may create differential susceptibility to other agents in work environments such as lead, irradiation, alcohol, and certain chemicals, pesticides, and drugs $[42,43]$. We currently recognize that there is a complex relationship between exposure to occupational and environmental hazards and the reproductive health of both sexes, but empirical data are still quite limited, and few, if any, come from Latin America.

Reproductive health consequences of women's economic activities

How Latin American women's economic roles structure their fertility can also have important implications for women's health, yet there has been little work that directly addresses this subject. There is abundant research on the social structural and psychological determinants of female fertility in the developing world, and on the factors that might induce Third World women to have fewer children [44-52]. Extensive research has also examined the relationship between macro-level socioeconomic processes and demographic patterns [53-56]. More recently, some interesting accounts have appeared of how women's economic roles influence their fertility behavior. For example, Safa [57] describes how female Brazilian factory workers delay marriage and pregnancy because they would lose their valuable jobs if they became pregnant. And Young's [58] research in two Oaxacan municipios shows that fertility increased after 1930 , secondary to a decline in women's economic activities outside the home. Yet neither of these studies, nor any others I am aware of, have considered how women's productive and reproductive roles act together on their health. I will, therefore, draw my own field research in Colombia and Mexico to identify some issues.

\section{Case 1: reproductive health consequences of economic dependency}

The fertility and reproductive health of Latin American women are acutely affected by the processes of uneven economic development seen throughout the region today. In the cities, one result is a lack of jobs for unskilled workers of either sex, but women encounter more obstacles than men in their search for paid employment [26, pp. 25-37: 27, pp. 129-141]. Those with dependent children who need to work are additionally handicapped because most of the available jobs are incompatible with simultaneous child care. It is further difficult for women with children to combine work and family roles due to the absence of public child care facilities and because, in many cases, kin are unwilling or unable to regularly care for children who arc not theirs [59]. As a result, when women discover they are pregnant, they seek to establish a dependable relationship with a man who will provide for them and their children, if they do not have such a relationship already. But many women find they are unable to create or continue stable conjugal relationships and they turn to illegal abortion to end their pregnancies.

Ten years ago, the International Planned Parenthood Federation conservatively estimated that close to five million illegal abortions were performed annually throughout Latin America, with the incidence highest in the largest cities [60]. Since that time, the number of illegal abortions performed each year continues to grow [61], and now at least one third of all known pregnancies are ended in this manner. Women rely on a variety of means to abort unwanted pregnancies, all of which can have negative consequences for their health. For a study of abortion decision making in Cali, Colombia in 1974-75. I interviewed 108 women with unwanted pregnancies. The women came primarily from working class and lower class backgrounds. Fifty-nine of their pregnancies were ended by illegal abortion: $50 \%$ by catheterization; $33 \%$ with herbs, pills, and injections; and $14 \%$ with dilation and curettage. (The rest used other means.)

The health complications of these induced abortions were considerable. Nearly $30 \%$ of the women required hospitalization, with hospital stays lasting 2 days or more in $71 \%$ of the cases. More than a fourth also reported emotional aftereffects of the abortion such as nightmares, anxiety, and depression; more than $60 \%$ described the experience as one of the worst, if not the worst, of their lives. And, of course, health complications were by no means restricted to those whose abortion attempts were successful. Sixtytwo percent of the women in the study population who described their pregnancies as unwanted, but who nevertheless continued them to term, reported at least one attempt to abort the pregnancy as well. In most cases, they used herbal emmenagogues or injections, often the very same ones used by those who successfully aborted their pregnancies. Although I lack quantitative data on the health effects of these unsuccessful abortion attempts, they should not be ignored in future research on the subject. 
The experiences of this Cali study population seem typical of Latin American women who seek illegal abortion [62]. The Westinghouse prevalence surveys conducted in the late 1970 s found that the proportion of women who required hospitalization following their last abortion ranged from $36 \%$ in São Paulo. Brazil to $51 \%$ in Panama City [63]. In Santiago, Chile and Mexico City, hospitalization rates for abortion complications arc a minimum of $40 / 1000[60$, p. 44]. Yet physical damage and emotional pain are not the most severe consequences of this procedure. Abortion complications are the leading cause of death among women of childbearing age in most major Latin American cities. The Inter-American Investigation of Mortality found that abortions were responsible for $34 \%$ of maternal deaths in 10 cities throughout Latin America [23, p. 6].

Case 2: reproductive health consequences of economic indispensability

In the rural Mexican municipio (township) of San Francisco (a pseudonym), Oaxaca, women's economic roles also structure their reproductive behavior, causing characteristic health sequelae. Here, however, economic pressures interact with political ones to generate a fertility pattern opposite that seen in Cali and similar urban settings. Fertility in San Francisco is high, induced abortion rare, and women are loath to use any artificial means to limit their fertility.

San Francisco is a Chinantec-Spanish speaking community of about 300 families of subsistence cultivators located in Oaxaca's Sierra de Juárez. As in other indigenous communities in Latin America [64], women in San Francisco (Franciscanas) contribute importantly to their households' subsistence. In addition to performing copious domestic chores, the vast majority also work their own fields; about a third earn cash as well. Many singlehandedly run their family's farms or maintain their families by other economic means during their husbands' periodic terms of unpaid community service (cargos), or when their husbands are absent from the community for other reasons. Women take pride in their contributions to their households' economic well-being, and they derive an important part of their female self-identity from these productive activities.

Their economic indispensability leads Franciscanas to fear any illness that would leave them unable to work. Therefore, although most say they already have all the children they want, they adamantly refuse the contraceptives available in the town's two health centers, for they fear these remedies would damage their health by causing protracted, and possibly incurable illness or even death. They are further unwilling to experiment with contraceptives because they fear that should they become ill, any remedy powerful enough to cure the problems that the contraceptive had caused would be far outside their own financial reach.

Franciscanas' attitudes about birth control must be interpretcd within a broader political economic context for them to be fully understood [65]. In San Francisco today, maintaining a population base of sufficient size to sustain the collectivity is a constant source of concern. A large male population is needed to defend the community's borders against armed attack by members of land-hungry neighboring municipios. A formidable population is further needed to forestall federal efforts to administratively consolidate San Francisco with other nearby municipios because it is now considered by the government to be far too small for designation as an independent entity. Accelerated out-migration and disease have eroded the community's size and strength so that, at present, the community perceives itself to lack sufficient able-bodied members to survive. These elements lead members of the community to exert relentless social pressure on Franciscanas to be prolific, and to negatively sanction any who openly seek to limit the size of their families.

This combination of economic and political pressures on women to bear many children has important negative consequences for Franciscanas' health. Postpartum complications are very common throughout the community. Of the 180 women we interviewed, two-thirds reported at least one health problem following a birth. These ranged from disorders the women themselves considered minor such as backaches, to more serious ones including prolapsed uteruses and uterine hemorrhaging. Women state that the demands of constant childbearing damage not only their reproductive systems, but their overall health. Their feelings are objectively based. My data show that, controlling for age, women who had four or more pregnancies reported significantly more minor health conditions including headaches, backaches, breast problems, and anger sickness (coraje). The higher-fertility women were also significantly more likely to report at least one major illness $[65$, p. 716$]$. Although I cannot at this time determine whether women with higher fertility also had shorter lives, given these findings, such an association would not be surprising.

The divergent fertility patterns seen in Cali, Colombia, and San Francisco, Oaxaca, are the result of complex macro-micro level interactions. Due to blocked access to independent economic means, pregnant Caleñas look to male conjugal partners and kin for help determining the fate of their pregnancies. Many who cannot find someone to support them and their children seek illegal abortion, with physical and emotional complications the frequent results. Thus, many fertility choices in Cali are based primarily on a woman's direct and indirect access to economic means. In contrast, in San Francisco, the needs of the collectivity for women to be prolific reinforce those of individual households which depend on women's economic contribution and therefore discourage them from using contraceptives or resorting to abortion because either could damage their health. Here, economic and political forces act in concert to prevent women from controlling their fertility, overpowering the personal desires many Franciscanas have for fewer children. As in the Colombian situation, physical and emotional health sequelae result from the reproductive practices seen in San Francisco. Therefore, in future studies of the relationship between economic development and women's health in Latin America, the reproductive antecedents and consequences of women's economic activities must also be considered. 


\section{WOMEN'S ROLE IN HOUSEHOLD HEALTH}

Sickness is an important part of the reality within which life's daily activities are carried out in most of the developing world. High infant and adult mortality rates tell only part of the story. Although reliable morbidity data are harder to obtain, one recent piece of research provides a rough gauge of the extent of the problem. Health data collected from 100 ambulatory ill adults in three rural Mexican communities revealed that $85 \%$ were anemic, and $74 \%$ were infected with intestinal parasites [66]. Although we cannot easily generalize to a larger population from these findings, it is nonetheless clear that these rates compare unfavorably with the rates for these same illnesses in any industrialized country. Although I collected no systematic data on the subject in the Oaxaca municipio where I recently worked, many of the adults and children I observed suffered from a host of chronic health conditions, the most common of which were respiratory infections, gastrointestinal complaints, skin ulcers and other persistent skin problems, and nonspecific pains, malaise, and weakness. Ferguson's research in a medium-sized $\mathrm{El}$ Salvador town confirms my own observations. About a typical family from whom she collected longitudinal health data, she writes:

[Mrs Musto's] children were sick with upper-respiratory or gastro-intestinal infections on each of the six home visits made during the course of the survey. In the case of the Mustos' children, as in similar cases, it was difficult to determine when one illness ended and another began. The children chronically suffered from acute conditions [67].

In many parts of Latin America, sickness is a fact of daily life, and in most cases, it is women who are responsible for maintaining household health and treating illness. There is, of course, no intrinsic reason why this division of labor exists, since what is considered women's work varies markedly throughout the world [68]. It is likely that these responsibilities are normally allocated to women because they are viewed as extensions of their role in the reproduction of society.

There is, however, growing recognition of the fact that most women possess significant specialized knowledge concerning health care. This includes more than simply knowing how to provide their families with adequate food, fucl, and water, and how to dispose of household waste, although such tasks are ordinarily quite complex $[69,70]$. Women are also expected to meet the special needs of chronically ill, elderly, or disabled household members for diet, exercise, and rest. They also manage acute illness episodes by determining when family members are ill and deciding what kind of care they will receive. It is usually women who prescribe remedies, decide at what point in an illness to seek outside attention, and what type of practitioner to consult. They also socialize family members, especially children, concerning appropriate health beliefs, illness behavior, and patterns of health service utilization [71]. Work by Menćndez and his colleagues illustrates some of these general propositions. They interviewed 62 Mexico City school children from a variety of social classes about health care practices in their homes. The overwhelming majority of the children indicated that the person in charge of curative practices was their mother. Ninety-five percent advised their mothers when they did not feel well: $82 \%$ were cared for by their mothers when ill; $78 \%$ were given medications by them; and $90 \%$ said that their mothers taught them what they know about medications [72]. Finerman's research among the Saraguro of southern Ecuador presents similar findings. She reports that most of the mothers she interviewed could name between 50 and 100 medicinal plants. The women were also able to provide detailed descriptions of the plants' curative properties and methods of preparation and administration. On the other hand, men, children, and women without children could name only between five and ten herbal remedies and they were frequently misinformed about their curative properties and their manners of use [73].

When we recognize the extent to which most illnesses are treated at home, we gain an even better understanding of the significance of women's role in household health. Throughout both rural and urban Latin America, contrary to conventional wisdom, most illnesses are treated not by indigenous curers but by women themselves. There is abundant literature to prove this. Working, for example, among the Aymara of the Bolivian Altiplano. Bender reports:

... based on what the women told us . . traditional healers are not the main source of care. What we call "self-care" is far more prevalent. And women, for the most part, provide this care. There are exceptions to this, of course, and immunization of children is the most prominent. Other exceptions include occasional purchase of medicine, infrequent reference to actual use of a curandero [indigenous curer], and rare reference to use of a hospital in the rural area or in the city of La Paz. More often when asked, "Who cares for you when you are ill?", the answer is, "We do" [74].

In a typical interview, Bender was told, "We ourselves are the best. We never take our children to a curandero or a médico [doctor]... The curandero doesn't know too much; we know the same as he about herbs" [74, p. 13].

In her El Salvador study, Ferguson similarly found that mothers usually had exclusive responsibility for caring for sick children, including deciding whether to medicate them themselves or seek lay or professional referral, and which pharmaceuticals to buy [75]. She found that $52 \%$ of 186 illness episodes werc treated through home medication or lay referral, with women playing the major role by far in both of these health care activities [67, p. 113]. Working in Mexico City, Laurell and her colleagues [76] report that more than $25 \%$ of those interviewed relied only on self medication for their family's most recent illness, despite the fact that $63 \%$ of the study population were entitled to receive free health care from the government's Social Security health system. Woods and Graves' research in a highland Guatemala village also shows that most illnesses are treated at home. During a 6 month period, they found that $41 \%$ of the Indians and $35 \%$ of the Ladinos relied on selfmedication for the illnesses they experienced $(27 \%$ of the Indians and $30 \%$ of the Ladinos sought help from physicians or other healers; the remaining $32 \%$ and $35 \%$, respectively, did not treat the illnesses they experienced during the 6-month data collection 
period by any means) [77]. Although Woods and Graves do not present their data by sex, it would be surprising if women did not obtain and administer most of the home remedies to which they refer.

Whether in times past native healers were consulted more often than they are today cannot be determined. It is clear, however, that knowledge and use of traditional healing has declined with the introduction of modern medicine. In the Oaxaca municipio where I worked, younger women and those who lived along a highway which gave them easy access to city-based physicians had less knowledge of medicinal plants for the treatment of women's reproductive health problems and the management of reproduction than did older women and those who did not live near the highway. And the residents of that community unanimously believed that their ancestors knew more about herbal remedies than they did. Accompanying this loss of knowledge is a widespread loss of confidence in the curative powers of herbal medicine.

Research by Campos, Ruiz, and Zúniga support these impressions. They interviewed 30 Indian and 35 Mestizo residents of a community in Chiapas, Mexico. In conformity with the results of the studies cited above, they found that nearly everyone in both groups at least occasionally practiced selfmedication. But, they also found that the overwhelming majority of both groups $(87 \%$ of the Indians; $85 \%$ of the Mestizos) used patent medicines rather than herbal remedies to treat such common conditions as headaches, diarrhea, and coughs. Informants gave very straightforward reasons for preferring patent medicines, including: "They cure more rapidly." "They're more powerful." "They're better than herbs." "They enter the system faster." "One recovers more quickly from sickness." "They're patented" (patentidad) [78]. Laurell and her colleagues [76, p. 403] similarly report that only $6 \%$ of a stratified sample of 340 Mexico City households used home remedies instead of patent medicines to treat their last illness. And in Menéndez's and his colleagues' study of the health care practices of Mexican school children, they found that $57 \%$ of the mothers gave their children patent medicines when they were last sick, while only $4 \%$ gave them home remedies (the rest took their children to the doctor) [79].* The mothers' responses to the question, "How did you learn to use medicines?" are consistent with this pattern of preference for commercially manufactured medications. Nearly $80 \%$ said they learned about the medicines they use from physicians while only $18 \%$ mentioned their own mothers as their source of medical information. The loss of knowledge and confidence in traditional healing practices is symptomatic of the larger set of transformational processes seen throughout Latin America as villages, towns, and cities are drawn more tightly into a world economic system.

Yet despite an overall decline in the knowledge and use of herbal medicines throughout Latin America,

*While all of these findings may in fact underestimate the true extent of herbal remedy use, the pattern they present is consistent, and striking. some women continue to treat certain types of health conditions in a traditional way. Some of my own research in Cali has shown that most women there use herbal emmenagogues (menstrual inducing agents) and other nonconventional means of fertility control despite the availability of modern contraceptives [80]. In 1978, we interviewed over 200 primarily working class pregnant women about the management of early pregnancy. We found that nearly three-fourths of these young, predominantly urban-born women could name at least one emmenagogue, $54 \%$ had used emmenagogues at some point in their reproductive careers, and $41 \%$ had done so for their present pregnancy. Plants and herbs were the most frequently mentioned emmenagogues (38\%), followed by injections ( $34 \%$ ). Young women learn to use these remedies soon after menarche, primarily from older women in their households

Interestingly, we found no variables which differentiated the women with regard to their knowledge or use of these unconventional fertility control methods. Younger women were as likely as older women to know about and use them. Urban and rural born women were equally likely to be familiar with the remedies. Women who had used modern contraceptives were as likely as nonusers to have also tried herbal emmenagogues.

These data show that traditional health care practices persist when they meet specific needs. In times past, many Colombian women relied upon herbal emmenagogues and other post-conceptive fertility control techniques when cultural standards dictated that they be prolific and prohibited them from independent control over their reproductive function. Use of these post-conceptive techniques allowed women to surreptitiously end unwanted conceptions before the fact of pregnancy became publicly known. Today, these methods continue to be a popular way for Caleñas to control fertility, and, in fact, may be the fertility control technique most often used by Caleñas and women living in other Latin American cities. Many Latin American women do not like conventional contraceptives $[81,82]$. Yet they also lack the economic resources and the desire to rear many children. Because post-conceptive birth control is well integrated into women's informal health care practices and because the methods are widely available and perceived to be safe and effective, many women choose them over conventional contraceptives.

Thus, in order to understand women's role in household health, the health care decisions they make, and the health care practices they observe, it is necessary to look at macro and micro-level interactions. An example from my Mexican field work will further illustrate this point. The Oaxacan municipio I call San Francisco fiercely guards its semi-autonomous political status, and is chary of representatives from external agencies who seek to play a role in community life. One of the ways that the community of male householders attempts to limit the impact of outsiders is by insisting on community-wide consensus on issues of public concern. This edict of public unity was challenged by a group of local mothers after the Mexican federal government established a health clinic in the municipio. Most of the 
town's residents initially welcomed the clinic, using the services primarily for children's health care needs. With time, however, the vast majority abandoned the health care facility which came to be regarded, in part, as a symbol of excessive state penetration. It seemed likely that the government might withdraw the clinic for lack of use [83]. This change in public opinion did not dissuade a small group of female household heads from continuing to use the clinic's services. They even sought to expand these services by working as informal auxiliaries to clinic personnel. And, although these actions led to their censure by the (all male) town assembly for 'dividing' the community, the women did not change their behavior. I believe they were willing to defy the men's wishes because, as household heads, the women were freer than the rest of the community to act on what they felt were their children's best interests. In this case, their children's interests were perceived by the women to involve keeping open the medical facility. Other women were constrained from acting similarly by pressures from both their husbands and from the community as a whole [84]. Consequently, it must bc recognized that women's role in household health and the repercussions of their behavior are determined by interactions between macro-level forces such as those involved in the building of nation-states and micro-level processes including the distribution of power within households.

\section{DETERMINANTS OF HOUSEHOLD HEALTH}

The above data document how Latin American women serve as health care providers in the home and how they influence household health behavior. On the whole, that research designates the individual woman as the unit of analysis and it evaluates the impact of women's behavior on the health of other members of her household, primarily her dependent children. Yet there are also other factors pertaining to the composition, structure, and organization of households that also affect the health of women and children, although as yet there has been virtually no research on this subject.

This section therefore describes a series of research questions whose answers would deepen our understanding both of the determinants of women's health in Latin America and of the nature of the constraints that women face as health care consumers and health care providers in the home. By designating the household as my unit of analysis, I do not seek to minimize powerful role that macro-level processes also play in determining patterns of health, illness, and disease [85-88]. But households represent an important bridge between individuals and society, for they provide the context in which individuals sustain themselves and carry out daily life. As such, household studies can provide a link between macro historical-structural approaches that are concerned with the political economy of development and microeconomic and ecological analyses of the determinants of individual behavior $[89,90]$. Although household studies are themselves still in their infancy [91], we can identify some structural and organizational features of households that can affect the health of women and other household members.
Household composition, structure, and organization

Households, or domestic groups, are groups of people who live together and form functioning social and economic units; their members are not necessarily related by marriage or blood [92]. Throughout Latin Amcrica, houschold composition markedly varies. There are societies where the nuclear family (i.e. a couple and their dependent children) is both the ideal household and the statistical norm, those where it is only the ideal, and those where it is neither the ideal nor the norm [93].

Household composition, particularly the presence or absence of a male household head, would be expected to significantly influence the health of women and other household members. Throughout both rural and urban Latin America the proportion of female-headed households is increasing [94]. In rural areas, female-headed households most often result from the death of the husband, or from his tcmporary or permanent migration. Their frequency is quite variable, but generally not more than $10 \%$ of rural households are headed by women. In urban centers, female-headed households are more common, accounting for up to $25 \%$ of households in many Latin American cities [95]. Young single women of childbearing age migrate to the cities in larger numbers than men for a number of reasons, including the fact that there is now less need for female labor in the rural areas [96], and there is a steady demand for unskilled female domestic servants in the cities. For example, in 1974 there were 79 men for every 100 women between the ages of 20 and 24 in Colombia's four largest cities, and 83 men for every 100 women in the 20-44-year-old age group [97]. One outcome of this imbalance is an increasing number of temporary and sporadic sexual unions [24, p. 80;98-100]. When these unions end, the children remain with their mothers, who maintain or then establish their own households.

Although I could find no research that directly compared the health or nutritional status, or health behavior of individuals living in female and maleheaded households, there are some suggestive indirect findings. It should, however, be remembered that female-headed households are found in all social sectors and that many women are household heads only for temporary periods, either because their partners are intermittently absent or due to the practice of serial monogamy. Nevertheless, data from a variety of sources reveal that members of femaleheaded households are more likely to live in poverty $[98$, p. $231 ; 101]$. This is because women are more apt to be unemployed, or if employed to earn less than men. In addition, unlike male-headed households which can often count on the supplementary earnings of the wife, female-headed households have fewer supplementary workers, or they have secondary workers who are female and thus faced with the same constraints on jobs and income as is the household head herself [38, p. 246].

The implications of these economic findings for the health of household members are not clear. Members of female-headed households may be in generally worse health due to their poverty alone. They are more likely to live in areas with substandard housing, unsafe drinking water, and inadequate sewers. There 
may not be sufficient income for them to eat nutritionally balanced diets, and pay for medical visits, pharmaceuticals and other health care supplies. Members of such households might be more likely to delay in seeking medical assistance, or they might consult with less competent practitioners because they may charge less for their services. On the other hand, there are data from Africa and India which show that although female-headed households are disadvantaged economically, they have relatively fewer than average underweight children [102, 103]. Nelson suggests that this unexpected finding occurs because children's nutritional status depends less on overall household income than it does on the income of the mother. She cites several studies which demonstrate that while women ordinarily use the economic resources they control to buy food for their families or to meet other basic needs, men often use their resources for productive investments, consumer goods, or entertainment [104]. But, whether the nutritional differential between male and female-headed households is large enough to result in better health for the members of female-headed households is not clear from these reports.

In addition to the sex of the household head, there are other variables in the structure and organization of domestic groups that can also influence the health of women and other household members [105]. These include: the size of the domestic group; whether the domestic group consists of a married couple and their dependent children (i.e. a nuclear household) or whether other kin also live in the household to form an extended unit; who these other kin are; whether the household is made up of family, friends, strangers, or some combination of the three; the ages, sexes, and marital situations of the economically productive members of the household; whether economic resources are pooled or whether their control is retained by those who earn them; how decisions regarding the allocation of domestic work and responsibilities are made. For instance, in both Cali, Colombia, and San Francisco, Oaxaca, domestic groups made up of a couple and the wife's parents are said to function more smoothly and cooperatively than those made up of a married couple and the husband's parents. All of these variables can influence household health, but since I could find no empirical work to reveal the nature of the associations, I will simply list below what I see as some of the relevant issues in the interest of stimulating research.

Household economics. How are decisions regarding the use of economic resources for health care made? Do the opinions of all adult household members count equally or only the opinions of the economically active members? When are criteria other than an individual's economic contribution more significant? How are conflicts over domestic expenditures for health care resolved? How are health care needs balanced against expenditures for food and other household needs? How do decisions regarding the use of household resources for health care change over time? What factors are responsible for these changes? How do the periods of unemployment, less than full employment, and full employment of a household's wage earners influence expenditures for health? What impact do conflicts between the work and family roles of a household's members have on household health?

Recent work on the 'new home economics' [106-108] could provide insight into some of these issues, along with methodological strategies for conceptualizing future research. However, much of this work is flawed by being static, reductionistic, oblivious to domestic power differentials, and by its failure to consider the significance of macro-level constraints on individual action or the social implications of economic behavior [109]. Attention to considerations such as the following would help make 'new home economic' approaches more useful for understanding the determinants of women's health and household health in Latin America.

The distribution of domestic power. When there are simultaneous illnesses in a household and limited economic resources, who gets treated? Who gets treated first? Whether or not economic resources are limited, who decides whose health problems and what kinds of health problems are given priority? Are there differences in the way a household responds to an illness episode based on the sex of the sick member [110]? Are there differences based on the sex of the household head? Although statistics from Latin America show higher female mortality in children aged $1-4$ in 11 of 18 Latin American nations, without more detailed data we cannot conclude that differential treatment of children by sex is at the core $[10$, pp. 92-93; 110, p. 11; 111, 112]. Do older children receive less medical attention or less prompt medical attention when they are ill because they are perceived to be stronger? Are they given more or more rapid medical attention because they already survived the critical high childhood mortality period? Are the illnesses of frailer children neglected because they are not expected to survive [113]? Are their illnesses promptly treated in the hope of prolonging the child's existence? And again, who makes these decisions and how are they made?

Household organization. How do the illnesses of household members of different sexes, ages and social statuses affect household functioning? What roles do household size, structure, and composition play in determining the impact of illness on a domestic group? Does household fission or fusion result from certain kinds of illnesses, or from the illnesses of certain household members? Which ones? How are patterns of sharing within a domestic group affected by illness? Who cares for sick household members? Who takes off time from work? How are such decisions made? How are decisions regarding what types of practitioners to consult (e.g. government clinic, lay curer, private physician, nurse, neighbor) and when to consult them arrived at? How are decisions to change practitioners made? As discussed in the previous section, we know that women usually play a major role in these caretaking tasks and illness management decisions, but we lack information on how tasks are allocated and decisions arrived at in households with several female members, as is often the case in Latin America, particularly among the poorer groups. Similarly, data are lacking on the circumstances under which women will not act in these caretaking roles. 


\section{Limitations of the household concept}

Using the household as the conceptual and methodological unit to cast light on the determinants of Latin American women's health and their role in household health has the advantage of allowing investigators to study the actual social contexts in which much behavior, activity, interaction, and information exchange about health occur. Nevertheless, as Anker and his colleagues [114] caution, there are limitations with this approach. One problem is the tendency of investigators to conceptualize the household as a homogenous unit, thereby implicitly assuming that the behavior of the aggregate unit-the household-is equivalent to the behavior of the individuals who comprise it. Another difficulty is the frequent assumption that all households consist of a single family unit when in fact two or more separate families may occupy the same dwelling, and cooperate for some purposes but not for others. In addition the term household as it is conventionally used implies that biological reproduction, socialization, economic production and maintenance are all carried out within the same physical unit. Although this may be true in some parts of the world, it is not necessarily the case in many Latin American societies. Furthermore, it is incorrect to suppose that the household head can accurately represent the interests of all other members of a household [114, pp. 21-22]. Rather, differences in the interests and resources of household members should be assumed, and they should be analyzed as to their implications for household health.

Childbearing decisions can be used to illustrate the kind of conflict over health that can occur within domestic groups. Although the nature of conflicts between conjugal partners over fertility decision making has received some attention $[59, \mathrm{pp} .101-105 ; 115$, 116], less interest has been shown in how conflicts over fertility between a pregnant woman and other members of her domestic group are resolved. My own study of how women in Cali, Colombia decide to seek illegal abortion revealed that their own co-resident kin played a major role in women's decisions to continue unwanted pregnancies when the woman had no reliable source of male support. Women usually first discussed their pregnancies with their conjugal partners who either expressed a willingness to financially support them and their children, or encouraged them to end the pregnancy. Women whose partners advised an abortion but who wanted to continue the pregnancy did so if they could obtain a commitment from other relatives to provide financial help and/or child care after the birth. Conversely, the lack of an economically supportive domestic group strengthened women's resolve to seek an abortion [117]. The extra-conjugal members of women's domestic groups influenced the fertility decision making process in another way as well. In most cases, women believe that their relatives will try to stop their abortion attempts if they know about them. Therefore, the overwhelming majority of the women interviewed did not discuss their decision to seek illegal abortion with members of their domestic groups other than their conjugal partners, because they knew they would try to prevent the abortion $[117, \mathrm{p} .100]$.

Therefore, even within a household, consensus cannot be assumed in matters of household health Conjugal partners may disagree over the proportion of the domestic budget that is allocated to nutrition and health, as I have already described. Intergenerational conflicts may revolve around the best way to treat sick children. And conflicts over a woman's pregnancies and whether or not to continue them may occur between a woman and any or all of the other members of her domestic group. How these and similar conflicts are resolved will have important implications both for the functioning of the domestic group and for household health.

Households, however, rarely exist in a vacuum. They are linked by a network of extra-domestic social ties to a variable number of individuals and groups. As Oppong correctly states, "Domestic groups may... be thought of as those basic units that revolve around the processes of reproduction and production, but these processes central to the maintenance of human life are not necessarily carried out by a single-boundary maintaining unit. .." [118]. Studies of households removed from their broader social context therefore yield incomplete information. The composition, quantity, quality, and content of a household's extra-domestic social network can also have important implications for household health. For example, working in Aberdeen, Scotland, McKinlay [119] found that people whose social networks were mostly kin were less likely to be directed to the formal health care system than were those who had mostly friends in their social networks. We do not know the extent to which a similar pattern would be found in Latin America, but its potential implications for household health are clear.

There are many other issues in which the availability of extra-domestic social resources is likely to influence household health. These include: Under what circumstances will food be regularly shared across household lines? Under what circumstances will it be shared sporadically, such as in times of unemployment or in other emergency situations? To what extent is children's nutrition a function of the kind of social network a household maintains? For instance, do children regularly or occasionally receive snacks or meals in homes other than their own? Are households with sparse social networks disadvantaged because they have less access to sources of information about the formal health care system or about informal health care practices and techniques? Are newly arrived migrants disadvantaged for the same reason?

Research on differences in infant feeding practices in rural and urban areas will illustrate the potential relationship between the presence of domestic and/or extra-domestic social resources and household health. The data consistently show that urban women are less likely to breastfeed and that they breastfeed for shorter periods than rural women do. Although many who abandon breastfeeding give "insufficient milk' as the reason, research has shown that the problem more likely lies with the women's misunderstanding of the composition, consistency, and appearance of human milk and lack of knowledge about proper breastfeeding technique [120-122]. It has been hypothesized that women who are socially isolated because of recent migration or for other 
reasons will be more likely to abandon breastfeeding prematurely because they lack sources of guidance regarding successful breastfeeding technique [123] Similarly, more isolated women might be less likely to learn of a free government-sponsored Well Baby program; their children could cxperience retarded growth and development as a result. Therefore, in studying women's health and their role in the health care of other household members in both Latin America and other parts of the developing world, we may find that the availability of social resources outside a household may prove just as significant as is the structure and composition of a domestic group itself in determining the manifest picture.

\section{CONCIUSIONS}

This account has sought to show that households can provide a powerful lens through which to view the effects of uneven capitalist expansion and development on health in Latin America. In doing so, particular attention has been paid to women's health and to women's roles as health care providers in the home and allocators of household resources for health care needs. Throughout contemporary Latin American, far-reaching changes in women's productive roles, and in the articulation between their productive and reproductive activities are having profound effects on women's health and on that of other household members. Yet as the sparsity of data show, we understand very little about the variety of forms these transformational processes take or their health implications. To obtain greater insight into these issues would require the following kinds of research:

(l) In-depth, diachronic studies that document how changes in the nature of women's productive and reproductive roles, and the relative importance that societies place on each at varying historical periods affect women's own health and their roles as health care providers and consumers. Especially useful would be studies contextualized by macro-level data on changing modes of production, the growth and expansion of capital, and related processes of economic differentiation, class formation, and proletarianization.

(2) Greater reliance on qualitative research approaches that derive from participant observation, personal testimony, and life history would allow women to use their own words to tell their own stories. Such data could challenge some of the false assumptions. misconceptions and unwarranted generalizations about women and their experiences that permeate society, not only in the domain of health and illness, but more broadly as well.

(3) Latin American women's importance in household health underscores their potential significance in organized cfforts to promote change in health conditions and health policy. Action-oriented research is needed on issues Latin American women themselves define as relevant to their own priorities, needs, and goals. For research of this type to be successful, women must participate fully in indentifying the issues, conceptualizing the study's scope, and collecting and analyzing the data. A participatory ap- proach to research on women's health and household health in Latin America would most effectively facilitate women's own efforts to achieve social change.

Acknowledgements - This paper was prepared for a Social Science Research Council Conference on 'The Political Economy of Health and Disease in Africa and Latin America' which was held in Toluca, Mexico, 8-12 January, 1985. An abbreviated version was also presented at the 13th International Conference of the Latin American Studies Association in Albuquerque, 18-21 April, 1985. Research in Colombia was supported by the National Institute for General Medical Sciences, the International Center for Medical Research and Training, Tulane Unversity/ Universidad del Valle, and the Wayne State University Office of Sponsored Programs and Research. Research in Mexico was funded by the National Science Foundation, the Wenner-Gren Foundation for Anthropological Research, the National Institute for Child Health and Human Development, and the UCLA Committee on Research. Arthur J. Rubel and Christine Ho read and commented helpfully on an earlier version of the manuscript.

\section{REFERENCES}

1. Banguero H. Socioeconomic factors associated with malaria in Colombia. Soc. Sci. Med. 19, 1099-1104, 1984.

2. Chapin G. and Wasserstrom R. Agricultural production and malaria resurgence in Central America and India. Nature 293, 181-185, 1981

3. D'Alessandro A. El problema de la enfermedad de Chagas en el Hemisferio Occidental. Bol. Ofic. Sanit. Panam. 76, 242-247, 1974.

4. Hamon M. J. and Kartman L. Oncocerciasis. Bol. Ofic. Sanit. Panam. 73, 54-56, 1972.

5. Menéndez E. L. Poder, Estratificación y Salud: Análisis de las Condiciones Sociales y Económicas de la En. fermedad en Yucatán. Centro de Investigaciones y Estudios Superiores en Antropología Social. Ediciones de la Casa Chata No. 13, México, 1981.

6. Organización Mundial de la Salud. Aspectos clínicos de la enfermedad de Chagas. Informe de una reunión conjunta OMS/OPS de investigadores. Bol. Ofic. Sanit. Panam. 77, 141-158. 1974.

7. Ortiz Mariotte $C$. Historia de la lucha antioncocercosa en México. Bol. Epidem. 27, 7-16, 1963.

8. Pan American Health Organization (PAHO). Research and Control of Onchocerciasis in the Western Hemisphere. Proceedings of an International Symposium. Scientific Publication No. 298. PAHO, Washington, D.C., 1974.

9. Pinto Dias J. C. and Borges Dias R. Las viviendas y la lucha contra los vectores de la enfermedad de Chagas en el hombre, en el estado de Minas Gerais, Brasil. Bol. Ofic. Sanit. Panam. 93, 453-467, 1982.

10. University of California, Los Angeles (UCLA). Statis tical Abstracts of Latin America. UCLA Latin American Center Publications, Los Angeles, Calif., 1956-1984.

11. Freudenberg $\mathbf{N}$. The effect of the economic miracle on public health and nutrition in Brazil. In Imperialism, Dependency, and Health. The Political Economic Determinants of Health and Nutrition. Case Studies in Latin America, pp. 58-65, HMO Packet No. 6, Health Marxist Organization, New York, 1979.

12. Weil C. Morbidity, mortality and diet as indicators of physical and economic adaptation among Bolivian migrants. Soc. Sci. Med. 13D, 215-222, 1979.

13. Wood C. H. Infant mortality trends and capitalist development in Brazil: the case of São Paulo and Belo Horizonte. Latin Am. Perspect. 4, 56-65, 1977. 
14. Dewey K. G. The impact of agricultural development on child nutrition in Tabasco, Mexico. Med. Anthrop. 4, 21-54, 1980.

15. Brown J. K. A note on the division of labor by sex. Am. Anthrop. 72, 1073-1078, 1970.

16. Edholm F., Harris $O$. and Young K. Conceptualizing women. Crit. Anthrop. 3, 101-130, 1977.

17. Benería L. Reproduction, production and the sexual division of labour. Cambridge J. Econ. 3, 203-225, 1979.

18. Browner C. H. Producción, reproducción, y la salud de la mujer: un estudio de caso de Oaxaca, México. Paper presented at the Annual Meeting of the Society for Applied Anthropology, Oaxaca, Mexico, 1987.

19. Medrano D. and Villar R. Problemas de salud y trabajo en los cultivos de flores de la Sabana de Bogotá: La visión de las mujeres trabajadoras en torno a su situación. Unpublished manuscript in author's files.

20. Carrillo J. and Jasis M. La salud y la mujer obrera en las plantas maquiladoras. El caso de Tijuana. Paper presented at the Annual Meeting of the Society for Applied Anthropology, San Diego, Calif., 1983.

21. Fernández Kelly M. P. A cross-cultural comparison of export-processing zones in Asia and the U.S.-Mexico border, pp. 61-74. Unpublished manuscript in author's files.

22. Laurell, A. C. Work and health in Mexico. Int. J. Hlth Serv. 9, 555-560, 1979.

23. Pan American Health Organization (PAHO). Women in Health and Development. A Guide to the Five-Year Regional Plan of Action on Women in Health and Development in the Americas, Scientific Publication No. 448. PAHO, Washington, D.C., 1983.

24. Pan American Health Organization (PAHO). Health of Women in the Americas, Scientific Publication No. 488. PAHO, Washington, D.C., 1985.

25. International Labour Office (ILO). Women at Work, No. 1, p. 14. ILO. Geneva, 1985

26. Arizpe L. Women in the informal labor sector: the case of Mexico City. Signs: J. Women Cult. Soc. 3, 30, 1977.

27. Jelin E. Migration and labor force participation of Latin American women: the domestic servants in the cities. Signs: J. Women Cult. Soc. 3, 129, 1977.

28. Segura de Camacho N. Reproducción social, familia y trabajo. Cali: historias de caso. Bol. Coyunt. SocioEcon. 8, 30-67, 1982.

29. See, for example, Birdsall N. Population and poverty in the developing world. World Bank Staff Working Papers, No. 404, The World Bank, Washington, D.C., 1980.

30. Nag. M. Economic value and costs of children in relation to human fertility. In Fertility Decline in Less Developed Countries (Edited by Eberstadt N.), pp. 274-94. Praeger, New York, 1981.

31. Strober M. and Weinberg C. Strategies used by working and non-working wives to reduce time pressures. J. Consumer Res. 6, 338-348, 1980.

32. Stellman J. M. Women's Work, Women's Health: Myths and Realities, p. 82. Pantheon, New York, 1977.

33. Mechanic D. Sex, illness, illness behavior, and the use of health services. J. Human Stress 2, 29-40, 1976.

34. Nathanson C. A. Illness and the feminine role: a theoretical review. Soc. Sci. Med. 9, 57-62, 1975.

35. Nathanson C. A. Sex, illness, and medical care: a review of data, theory, and method. Soc. Sci. Med. 11, 13-25, 1977.

36. Waldron I. Employment and women's health: an analysis of causal relationships. In Women and Health: The Politics of Sex in Medicine (Edited by Fee E.), pp. 119-138. Baywood, Farmingdale, N.Y., 1980.

37. Merrick T. W. Employment and earnings in the infor- mal sector in Brazil: the case of Belo Horizonte. J. Devel. Areas 10, 337-354, 1976.

38. Merrick T. W. and Schmink M. Households headed by women and urban poverty in Brazil. In Women and Poverty in the Third World (Edited by Buvinic M. et al.), pp. 244-271. The Johns Hopkins University Press. Baltimore, Md, 1983.

39. Mazumdar D. The urban informal sector. Wld Devl. 4, 655-679, 1976.

40. Leslie J., Lycette $M$. and Buvinic $M$. Weathering economic crises: the crucial role of women in health, pp. 17-18. Paper presented at the Second Takemi Symposium on International Health, School of Public Health, Harvard University, Cambridge. Mass., 1986.

41. Bunster X. Market sellers in Lima. Peru: talking about work. In Women and Poverty in the Third World (Edited by Buvinic M. el al.). pp. 92-103. The Johns Hopkins University Press, Baltimore, Md, 1983.

42. Flling R. Industrialization and occupational health in underdeveloped countries. Int. J. Hlth Sert. 7, 209-235, 1977.

43. Hatch $M$. Mother, father, worker: men and women and the reproduction risks of work. In Double Exposure: Women's Health Hazards on the Job and at Home (Edited by Chavkin W.), p. 166. Monthly Review Press, New York. 1984.

44. See, for example, Berelson, B. KAP studies on fertility. In Family Planning and Population Programs (Edited by Berelson, B. et al.), pp. 655-668. University of Chicago Press, Chicago, Ill., 1966.

45. Davis $\mathrm{K}$. Institutional patterns favoring high fertility. Eugenics Q. 2, 33-39, 1955.

46. Davis K. and Blake J. Social structure and fertility: an analytical framework. Econ. Dev. Cult. Change 4, 211-235, 1956.

47. Freedman R. The sociology of human fertility. Curr. Sociol. 10-11, 35-121, 1961-62.

48. Stycos J. M. Ideology, Faith, and Family Planning in Latin America. Studies in Public and Privale Opinion on Fertility Control. McGraw-Hill. New York, 1971.

49. See the following four references for critiques of this body of research: Fucaraccio A., Ovsienko V. E., Slutzky D., Singer P. I., Barclay W. Enright J. and Reynolds R. T. Imperialismo y Control de la Población. Ediciones Periferia S.R.L., Buenos Aires, 1973.

50. Gimenez M. E. Population and capitalism. Latin Am. Perspect. 4, 3-40, 1977.

51. Mass B. Population Target. The Political Economy of Population Control in Latin America. The Women's Educational Press, Toronto, 1976.

52. Latin American and Caribbean Women's Collective. Slaves of Slaves. The Challenge of Latin American Women. Zed Press, London, 1977.

53. See, for example, Glass D. V. and Eversley D. C. E (Eds) Population in History. Amold, London, 1965.

54. Harrison G. A. and Boyce A. J. (Eds) The Structure of Human Populations. Clarendon, Oxford, 1972.

55. Heer D. M. Economic development and fertility. De mography 3, 423-444, 1966.

56. Wrigley E. A. Population and History. Weidenfeld \& Nicholson, London, 1969.

57. Safa H. I. Women, production, and reproduction in industrial capitalism: a comparison of Brazilian and U.S. factory workers. In Women, Men, and the International Division of Labor (Edited by Nash J. and Fernandez-Kelly M. P.), pp. 95-116. State University of New York Press, Albany, N.Y. 1983.

58. Young $K$. Modes of appropriation and the sexual division of labour: a case study from Oaxaca. Mexico. In Feminism and Materialism: Women and Modes of Production (Edited by Kuhn A. and Wolpe A.), pp. 124-154. Routledge \& Kegan Paul, London, 1978 
59. Browner $\mathrm{C}$. Abortion decision making: some findings from Colombia. Stud. Fam. Plann. 10, 101, 1979.

60. Tietze C. Induced Abortion: A World Review, p. 44. The Population Council, New York, 1986.

61. Potts M. Abortion and contraception in relation to family planning services. In Abortion and Sterilization: Medical and Social Aspects (Edited by Hodgson J. E.), p. 487. Academic Press, London, 1981.

62. Cf. Noriega E. El Aborto (El Derecho de la Libre Maternidad). Editores Mexicanos Unidos, México, 1982.

63. The Johns Hopkins University Press. Pregnancy Termination. Population Reports, Series F, No. 7, July 1981.

64. Cf. Harris O. Complementarity and conflict: an Andean view of women and men. In Sex and Age as Principles of Social Differentiation (Edited by La Fontaine J.), pp. 21-40. ASA Monograph No. 17. Academic Press, London, 1978.

65. Browner $\mathrm{C}$. $\mathrm{H}$. The politics of reproduction in a Mexican village. Signs: J. Women Cult. Soc. 12, 710-724, 1986.

66. Rubel A. J., O'Nell C. W. and Collado-Ardón R. Susto. A Folk Illness, pp. 87 and 101. University of California Press, Berkeley, Calif, 1984.

67. Ferguson A. E. Commercial pharmaceutical medicine and medicalization, a case study from Ei Salvador. Cult. Med. Psychiat. 5, 125, 1981.

68. Murdock G. P. and Provost C. Factors in the division of labor by sex: a cross-cultural analysis. Ethnology 12 , 207. 1973.

69. See, for example, Elmendorf M. L. and Isely R. B. The Role of Women as Participants and Beneficiaries in Water Supply and Sanitation Programs, WASH Technical Report No. 11. Office of Health Bureau for Science and Technology. U.S. Agency for International Development under C-Task 51, Washington, D.C., 1981.

70. Isely, R. B. and Elemendorf M. L. Water and sanitation-related health constraints on women's contribution to the economic development of communities. In Women, Health, and Development (Edited by Aguwa M. I.), pp. 43-58. Michigan State University Office of Women in International Development, East Lansing, Mich., 1983.

71. Lewin $\mathbf{E}$. Women in health and healing systems: service and policy implications. p. 2. Unpublished manuscript in author's files, n.d.

72. Menéndez E. L. Automedicación, reproducción social y terapeutica y medios de comunicación masiva. In Medios de Comunicación Masiva, Reproducción Familiar y Formas de Medicina "Popular" (Edited by Menéndez E. L.), p. 29. Centro de Investigaciones y Estudios Superiores en Antropologia Social. Cuadernos de la Casa Chata No. 57, México, 1982.

73. Finerman R. D. Health care in an Andean community: getting the best of both worlds, p. 127. Unpublished Ph.D. dissertation, Department of Anthropology, University of California, Los Angeles, Calif., 1985.

74. Bender D. Women as promoters of health in the developing world. In Women, Health, and Development (Edited by Aguwa M. I.), p. 13. Michigan State University Office of Women in International Development, East Lansing, Mich., 1983.

75. Ferguson A. E. Class differences in women's roles as health care managers: a case study from El Salvador. Paper presented at the National Women's Studies Association Meetings, Champaign-Urbana, Ill., 1986.

76. Laurell A. C., Blando Blando A. and Heredia Duarte A. El desarrollo urbano y los patrones de consumo de productos farmaceuticos. Salud Públ. México 19, 397-410, 1977.

77. Woods C. M. and Graves T. D. The process of medical change in a Highland Guatemalan Town. In Latin American Studies, Vol. 21 (Edited by Wilbert J.), p. 19. University of California, Los Angeles, Calif., 1970.

78. Campos R., Ruiz A. and Zúñiga J. La automedicación en indigenas y mestizos: El caso de Tenejapa, Chiapas. In Medios de Comunicación Masiva, Reproducción Familiar y Formas de Medicina "Popular" (Edited by Menéndez E. L.), p. 132. Centro de Investigaciones y Estudios Superiores en Antropología Social. Cuadernos de la Casa Chata No. 57, México, 1982.

79. Escaleras J., de la Garza J, and Grajales C. Factores que intervienen en el desarrollo y mantenimiento de formas de "medicina popular": la automedicación. In Medios de Comunicación Masiva, Reproducción Familiar y Formas de Medicina "Popular" (Edited by Menéndex E. L.), p. 83. Centro de Investigaciones y Estudios Superiores en Antropología Social. Cuadernos de la Casa Chata No. 57, México, 1982.

80. Browner C. H. Traditional techniques for diagnosis, treatment, and control of pregnancy in Cali, Colombia. In Women's Medicine: Indigenous Methods of Fertility Regulation (Edited by Newman L.), pp. 99-123. Rutgers University Press, New Brunswick, N.J., 1985.

81. Hass P. H. Contraceptive choices for Latin American women. Populi 3, 14-24, 1976.

82. Nair N. K. and Smith L. Reasons for not using contraceptives: an international comparison. Stud. Family Plann. 15, 84-92, 1984.

83. Rubel A. J. Some unexpected health consequences of political relations in Mexico. Paper presented at the Annual Meeting of the American Anthropological Assaciation, Chicago, Ill, 1983.

84. Browner C. H. Gender roles and social change: a Mexican case study. Ethnology 25, 89-106, 1986.

85. McKinlay J. B. (Ed.) Issues in the Political Economy of Health Care. Tavistock, New York, 1984.

86. Flaherty D. et al. (Ed). The political economy of health. Rev. Rad. Polit. Econ. 9, 1977.

87. Navarro V. Social class, political power, and the state and their implications in medicine. Soc. Sci. Med. 10, 437-457, 1976.

88. Waitzkin H. The Second Sickness: Contradictions of Capitalist Health Care. The Free Press, New York, 1983.

89. Smith J., Wallerstein I, and Evers H. (Eds) Households and the World Economy. Sage, Beverly Hills, Calif., I984.

90. Netting R. M., Wilk R. R. and Arnould E. J. (Eds) Households: Comparative and Historical Studies of the Domestic Group. The University of California Press, Berkeley, Calif., 1984.

91. Schmink M. Household economic strategies: review and research agenda. Latin Am. Res. Rev. 19, 87-101, 1984.

92. Bohannon P. Social Anthropology, p. 86. Holt, Rinehart \& Winston, New York, 1963.

93. Yanagisako S. J. Family and household: the analysis of domestic groups. A. Rev. Anthrop. 8, 161-205, 1979.

94. Morrissey $M$. Female-headed households in Latin America and the Caribbean. Paper presented at the 13th International Conference of the Latin American Studies Association, Albuquerque, New Mex., 1985.

95. Ford Foundation. Women in the World. A Ford Foundation Position Paper, p. 8. Ford Foundation, New York. 1980.

96. Young $K$. The creation of a relative surplus population: a case study from Mexico. In Women and Development: The Sexual Division of Labor in Rural Societies (Edited by Beneria L.), pp. 165-167. Praeger, New York, 1982.

97. Departamento de Administración Nacional Estadistica (DANE). Población, empleo y desempleo, y desempleo urbano en Baranquilla, Bogotá, Cali, y Medellín. En- 
cuesta Nacional de Hogares, 7a etapa, p. 57. División de Censos y Proyectos Especificos, División de Estudios Sociales, Bogotá, 1974.

98. Youssef N. H. and Hetler C. B. Establishing the economic condition of women-headed households in the Third World: a new approach. In Women and Poverty in the Third World (Edited by Buvinić M. et al.), p. 235 The Johns Hopkins University Press, Baltimore, Md, 1983.

99. Browner C. and Lewin E. 'Female altruism reconsidered: the Virgin Mary as economic woman. $\mathrm{Am}$. Ethnol. 9, 61-75, 1982.

100. Browner C. H. Male pregnancy symptoms in urban Colombia. Am. Ethnol. 10, 494-510, 1983.

101. Jelin E. Women and the urban labor market. In Women's Roles and Population Trends in the Third World (Edited by Anker R. et al.), pp. 255-256. Croom Helm, London, 1982.

102. Safilios-Rothschild $C$. The role of the family in development. Fin. \& Dev. December, 44-47, 1980.

103. Fleuret A. Nutrition and food production: not as anthropologists see them. Rev. Anthrop. 13, 99, 1986.

104. Nelson N. Why has development neglected rura women? a review of the South Asian literature. In Women in Development, Vol. 1, p. 60. Pergamon, Oxford, 1979.

105. For a review of the literature on how variation in household size and structure may influence nutritional status see Hamilton S., Popkin B. and Spicer D. Women and Nutrition in Third World Countries, pp. 41-44. Bergin \& Garvey, South Hadley, Mass., 1984.

106. Becker G. A theory of the allocation of time. Econ. $J$. 80, 493-517, 1965.

107. Lloyd C. B. (Ed.) Sex, Discrimination, and the Division of Labor. Columbia University Press, New York, 1975.

108. Schultz T. W. (Ed.) Economics of the Family: Marriage, Children, and Human Capital. University of Chicago. Ill., 1974.

109. Sawhill I. V. Economic perspectives on the family. In The Economics of Women and Work (Edited by Amsden A. H.), pp. 125-139. Penguin, Harmondsworth, 1980.

110. For a review of the existing literature, most of which is about Asia, see Ravindran S. Health Implications of Sex Discrimination in Childhood. A Review Paper and an Annotated Bibliography. WHO Document FHE 86.2. 1986.

111. Cf. Miller B. D. The Endangered Sex: Neglect of Female Children in Rural North India. Cornell University Press, Ithaca, N.Y., 1981
112. Cf. Schultz T. P. Women's work and their status: rural Indian evidence of labour market and environment effects on sex differences in childhood mortality. In Women's Roles and Population Trends in the Third World (Edited by Anker R. et al.), pp. 202-236. Croom Helm, London, 1982.

113. Scheper-Hughes N. Women, work and infant mortality: a case study from Northeast Brazil. In Women and Work in the Third World: The Impact of Industrialization and Global Interdependence (Edited by $\mathrm{El}$ Sanabary N. M.), pp. 154-155. University of California Center for the Study, Education and Advancement of Women, Berkeley, Calif., 1983.

114. Anker R., Buvinić $M$. and Youssef N. H. Introduction. In Women's Roles and Population Trends in the Third World (Edited by Anker R. et al.), pp. 21-28. Croom Helm, London, 1982.

115. Hollerbach P. E. Power in Families, Communication and Fertility Decision-Making. Center for Policy Studies Working Paper No. 53. The Population Council, New York, 1980.

116. Ramos S. Maternidad en Buenos Aires: La Experiencia Popular. El Centro de Estudios de Estado y Sociedad (CEDES), Buenos Aires, 1981.

117. Browner C. Poor women's fertility decisions: illegal abortion in Cali. Colombia, p. 88. Unpublished Ph.D. dissertation, Department of Anthropology, University of California, Berkeley, Calif., 1976.

118. Oppong C. Family structure and women's reproductive and productive roles: some conceptual and methodological issues. In Women's Roles and Population Trends in the Third World (Edited by Anker R. et al.), p. 139. Croom Helm, London, 1982.

119. McKinlay J. B. Social networks, lay consultation and help-seeking behavior. Soc. Forces 51, 275-292, 1973.

120. Gussler J. D. and Briesemeister L. H. The insufficient milk syndrome: a biocultural explanation. Med. $A n-$ throp. 4, 145-174, 1980.

121. Greiner T., Van Estrik P., Latham M. C., Gussler J., Briesemeister L., Scrimshaw M. and Zhi-Chien Ho. Commentary on "The insufficient milk syndrome: a biocultural explanation." Med. Anthrop. 5, 233-260, 1981.

122. Cf. Wasserstrom R. Nestle in Mexico: hazardous to your health. In Imperialism, Dependency, and Health. The Political Economic Determinants of Health and Nutrition. Case Studies in Latin America, pp. 1-4, HMO Packet No. 6. Health Marxist Organization, New York, 1979.

123. Raphael D. The Tender Gift: Breastfeeding. Prentice-Hall, Englewood Cliffs, N.J., 1973.

Resumen-A pesar de que estudios recientes han identificado algunas de las relaciones entre el desarrollo enonómico capitalista desigual y la salud en América Latina, el impacto sobre, bien sea, la salud de las mujeres o la salud del hogar es en gran parte desconocido. El presente trabajo identifica varias áreas que urgen investigación. Este se concentra en el cómo los cambiantes roles de las mujeres y los patrones de producción doméstica afectan el comportamiento reproductivo de las mujeres, y las consecuencias de tales cambios sobre la salud de las mujeres y otros miembros de sus hogares. 